\title{
PENCATATAN NIKAH DALAM PENDEKATAN MASLAHAH
}

\author{
Sulastri Caniago \\ Program Studi Hukum Ekonomi Syariah STAIN Batusangkar \\ Jl. Jenderal Sudirman No. 137, Lima Kaum Batusangkar \\ e-mail: sulastricaniago@yahoo.com
}

\begin{abstract}
Marriage is basically the main element in the establishment of sakinah, mawaddah and rahmah family. Consequently, to realize such expected family, fixed laws are needed. The implementation of such laws in marriage is aimed at maintaining rights, ..... and responsibilities of the family members in order to realize everlasting and qualified family which is suitable with marriage purposes. Therefore, administrating marriage which has been stated in laws is becoming obligation to carry out. If it is viewed further from maslahah approach, administrating marriage can be included into maslahah in the level of dharuriyah in which such maslahah must be fulfilled unless it will jeopardize the existence of nasab.
\end{abstract}

Kata kunci: pencatatan, nikah, maslahah

\section{PENDAHULUAN}

V mat Islam masih memiliki cara pandang yang berbeda terhadap norma hukum dan peraturan yang ada. Di satu sisi dinyatakan bahwa sumber hukum Islam adalah alquran dan sunnah, di sisi yang lain bahwa dalam kedua sumber tersebut masih mengandung peluang ijtihad dalam persoalan yang belum diatur secara rinci atau penetapannya berdasarkan dalil zhanni. Ijtihad, sekalipun mengandung khilafiyah namun di kalangan sebagian masyarakat memiliki nilai sakralistik dan bersifat mengikat. Sementara ketika sebuah norma hukum itu telah diformulasikan dalam wujud perundangan-undangan masih dianggap suatu kesatuan yang terpisah dari hukum Islam itu sendiri, sehingga dengan mudah dikesampingkan. Persoalan ini di Indonesia masih belum mendapat tempat yang seutuhnya walaupun sudah lebih dari dari 20 tahun diundangkan. Hal ini berlaku dalam kasus pernikahan dan perceraian yang harus dicatatkan.

Pencatatan pernikahan dan perceraian bagi sebagian masyarakat hanya dipandang sebagai aturan hukum yang berbeda antara hukum Islam (figh) dengan ketentuan Undang-undang tentang pernikahan. Sehingga terjadinya dualisme pemahaman dan konsekuensi hukum. Sehingga pernikahan dan perceraian yang tidak dicatat ini lebih dikenal dengan istilah nikah dan cerai di bawah tangan. Bahkan untuk nikah dikenal juga istilah nikah sirri. Dari persolan ini penulis mengerucutkan tulisan ini kepada persoalan pernikahan yang tidak 
dicatatkan dan akan menguraikan lebih detail lagi tentang urgennya pencacatan nikah dalam pendekatan maslahah.

\section{PEMBAHASAN}

Pernikahan (perkawinan), merupakan sebuah lembaga yang memberikan legimitasi seorang pria dan wanita untuk bisa hidup dan berkumpul bersama dalam sebuah keluarga. Ketenangan atau ketenteraman sebuah keluarga ditentukan salah satunya adalah bahwa pernikahan itu harus sesuai dengan tuntutan syariat Islam (bagi orang Islam). Selain itu, ada aturan lain yang mengatur bahwa pernikahan itu harus tercatat di Kantor Urusan Agama sebagaimana yang dijelaskan dalam Undangundang Perkawinan tahun 1974 jo PP Nomor 9 tahun 1975 d Kompilasi Hukum Islam. (Amiur Nuruddin, Dkk, 2004: 122-123)

Pencacatan perkawinan pada prinsipnya merupakan hak dasar dalam keluarga. Selain itu merupakan upaya perlindungan terhadap isteri maupun anak dalam memperoleh hak-hak keluarga seperti hak waris dan lain-lain. Dalam hal nikah yang tidak dicatatkan dalam administrasi Negara mengakibatkan perempuan tidak memiliki kekuatan hukum dalam hak status pengasuhan anak, hak waris, dan hak-hak lainnya sebagai istri yang pas, akhirnya sangat merugikan pihak perempuan. (Ahmad Nuryani, 2012 : 1)

Secara fikih pernikahan secara bahasa bermakna al-wath'i dan al- dhammu wa al tadakhul yang artinya bersetubuh dan berkumpul. Secara bahasa didefinisikan sebagi akad yang ditetapkan oleh Syari' agar seorang laki-laki dan perempuan dapat mengambil manfaat untuk melakukan istimta' dengan seorang perempuan atau sebaliknya. (Wahbah Al-Zuhaily, 1989: 29)

Undang-undang perkawinan tahun 1974 memberikan definisi tentang perkawinan yang diatur dalam pasal 1 ayat 1 menyatakan bahwa perkawinan adalah "ikatan lahir batin antara seorang pria dengan seorang wanita sebagai suami istri dengan tujuan membentuk keluarga, rumah tangga yang bahagia dan kekal berdasarkan Ketuhanan yang Maha Esa" (Undang-undang Nomor 1 tahun 1974 tentang Perkawinan, 2005 :1-2).

Kompilasi hukum Islam memberikan definisi tentang pernikahan adalah akad yang sangat kuat atau miitsaqan ghalidhan untuk menaati perintah Allah dan melaksanakannya merupakan Ibadah (Inpres nomor 1 tahun 1991 tentang Kompilasi Hukum Islam, 2001: 1).

Ikatan perkawinan merupakan unsur pokok dalam pembentukan keluarga yang harmonis dan penuh rasa cinta kasih, maka dalam pelaksanaan perkawinan tersebut, diperlukan norma hukum yang mengaturnya. Penerapan norma hukum dalam pelaksanaan perkawinan terutama diperlukan dalam rangka mengatur hak, kewajiban, dan tanggung jawab masing-masing anggota keluarga, 
guna membentuk rumah tangga yang bahagia dan sejahtera.

$$
\text { Secara umum tujuan }
$$

pernikahan sebagaimana yang djelaskan oleh Imam Al-Ghazali dalam Ihya Ulumuddin yang dikutip oleh Abdur Rahman al-Ghazali adalah (Abdur Rahman Al-Ghazali, 2003: 24):

1. Mendapatkan dan melangsungkan keturunan secara sah. Firman Allah:

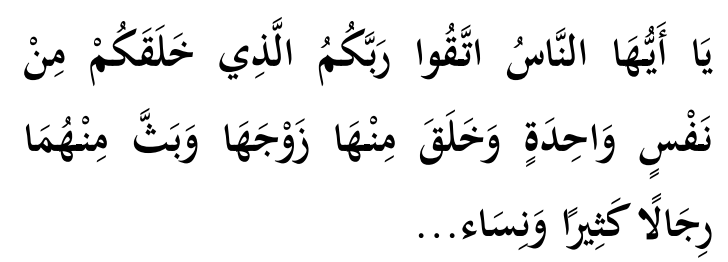

Wahai sekalian manusia bertakwalah kepada Tuhanmu yang menjadikan kamu dari diri yang satu dan darinya Allah menjadikan istri-istri, dan dari keduanya Allah menjadikan anak keturunan yang banyak, laki-laki dan perempuan... (Q.S. al-Nisa [4]: 1)

2. Memenuhi hajat manusia untuk menyalurkan syahwatnya dan menumpahkan kasih sayang;

3. Memenuhi panggilan agama, memelihara diri dari kejahatan dan kerusakan;

4. Menumbuhkan kesungguhan untuk menerima hak serta kewajiban dan;

5. Membangun rumah tangga untuk membentuk masyarakat yang tentram atas dasar cinta dan kasih sayang. Firman Allah Swt:

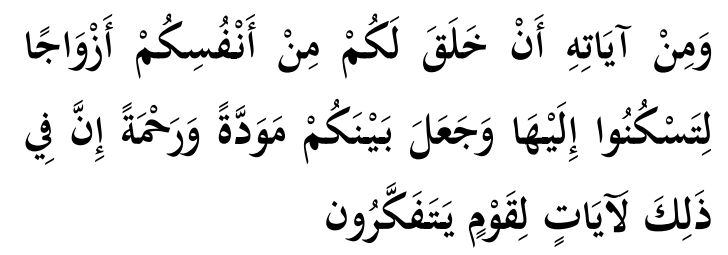

Dan di antara tanda-tanda kekuasaan-Nya, Dia (Allah) menciptakan untukmu isteri-isteri dari jenismu sendiri, supaya kamu cenderung dan merasa tenteram kepadanya, dan dijadikan-Nya di antara kamu rasa kasih sayang. Sesungguhnya pada yang demikian itu benar-benar terdapat tanda-tanda bagi kaum berpikir" (Q.S. al-Rum [30]: 21).

Undang-undang nomor 1 tahun 1974 tentang perkawinan menyatakan bahwa tujuan perkawinan untuk membentuk rumah tangga yang bahagia, kekal dan berdasarkan kepada Ketuhanan yang maha Esa. Sementara dalam kompilasai hukum Islam pasal 3 dinyatakan bahwa tujuan perkawinan adalah untuk mewujudkan kehidupan rumah tangga yang sakinah mawaddah, dan rahmah. Dengan demikian, maka sebenarnya tidak perlu diragukan lagi, apakah sebenarnya yang ingin dicapai dalam perkawinan itu. Tujuan perkawinan akan terkait pada frame of reference dari individu yang bersangkutan. Dengan demikian maka timbul pertanyaan bagaimana keluarga bahagia itu? Walaupun kebahagiaan itu relatif dan subyektif, tetapi adanya ukuran atau patokan umum yang dapat digunakan untuk menyatakan bahwa keluarga itu merupakan keluarga yang bahagia atau walfare (Eka Widiasmara, 2010 :13).

Keluarga merupakan keluarga bahagia bila dalam keluarga itu tidak terjadi kegoncangan-kegoncangan atau pertengkaran-pertengkaran, 
sehingga keluarga itu berjalan dengan baik tanpa goncangangoncangan atau pertengkaranpertengkaran yang berarti (free from quarelling) (Eka Widiasmara, 2010: 13).

Tujuan perkawinan yang lain selain membentuk keluarga bahagia, juga bertujuan lain yaitu bersifat kekal. Dalam perkawinan perlu ditanamkan bahwa perkawinan itu berlangsung untuk waktu seumur hidup dan selama-lamanya kecuali dipisahkan karena kematian.

Indonesia sebagai negara hukum telah mengatur tentang Perkawinan yang tertuang dalam Undang-Undang Perkawinan dan telah dilengkapi dengan Peraturan Pemerintah Nomor 9 tahun 1975 yaitu tentang pelaksanaan UndangUndang No. 1 tahun 1974 tentang Perkawinan, dan Intruksi Presiden Nomor 1 Tahun 1991 tentang Kompilasi Hukum Islam (KHI) dan peraturan-peraturan lainnya mengenai perkawinan.

Mengenai sahnya perkawinan dan pencatatan perkawinan terdapat pada Pasal 2 ayat (1) UndangUndang Perkawinan, yang berbunyi: "Perkawinan adalah sah, apabila dilakukan menurut hukum masingmasing agamanya dan kepercayaannya itu". Menurut Pasal 2 ayat (1) ini, kita tahu bahwa sebuah perkawinan adalah sah, apabila dilakukan menurut hukum masingmasing agamanya dan kepercayaannya itu. Hal ini berarti, bahwa jika suatu perkawinan telah memenuhi syarat dan rukun nikah atau ijab kabul telah dilaksanakan (bagi umat Islam) atau pendeta/pastor telah melaksanakan pemberkatan atau ritual lainnya, maka perkawinan tersebut adalah sah terutama di mata agama dan kepercayaan masyarakat. Tetapi sahnya perkawinan ini di mata agama dan kepercayaan masyarakat perlu mendapat pengakuan dari negara, yang dalam hal ini ketentuannya terdapat pada Pasal 2 ayat (2) Undang-Undang Perkawinan, tentang pencatatan perkawinan ialah tiap-tiap perkawinan dicatat menurut peraturan perundang-undangan yang berlaku. Pencatatan perkawinan bertujuan agar keabsahan perkawinan mempunyai kekuatan hukum, jadi tidak menentukan sah/tidaknya suatu perkawinan.

Bagi yang beragama Islam, ada aturan tambahan tentang sahnya sebuah pernikahan. Hal ini tertuang dalam pasal 4-6 Kompilasi Hukum Islam. Dalam pasal 4 dinyatakan "Perkawinan yang sah, apabila dilakukan menurut hukum Islam sesuai dengan pasal 2 ayat 1 Undang-undang No.1 tahun 1974" sementara dalam pasal 5 dinyatakan: Ayat 1: Agar terjamin ketertiban perkawinan bagi masyarakat Islam setiap perkawinan harus tercatat" bahkan dalam pasal 6 ayat 2 dinyatakan bahwa "perkawinan yang dilakukan di luar pengawasan pegawai Pencatat Nikah tidak mempunyai kekuatan hukum".

Bagi masyarakat Islam yang telah menikah namun tidak dapat membuktikan terjadinya perkawinan dengan akte nikah, dapat mengajukan permohonan itsbat 
nikah (penetapan/ pengesahan nikah) kepada Pengadilan Agama sebagaimana diatur dalam Pasal 7 Kompilasi hukum Islam (KHI). Namun Itsbat nikah ini hanya dimungkinkan bila berkenaan dengan: a. dalam rangka penyelesaian perceraian; $b$. hilangnya akta nikah; c. adanya keraguan tentang sah atau tidaknya salah satu syarat perkawinan; $d$. perkawinan terjadi sebelum berlakunya UU No. 1 tahun 1974 tentang perkawinan; $e$. perkawinan yang dilakukan oleh mereka yang tidak mempunyai halangan perkawinan menurut UU No. 1/ 1974. Artinya, bila ada salah satu dari kelima alasan di atas yang dapat dipergunakan, dapat mengajukan permohonan Istbat nikah ke Pengadilan Agama.

Sebaliknya, akan sulit bila tidak memenuhi salah satu alasan yang ditetapkan. Sedangkan pengajuan itsbat nikah dengan alasan lain (bukan dalam rangka perceraian) hanya dimungkinkan, jika sebelumnya sudah memiliki Akta Nikah dari pejabat berwenang. Sebagaimana telah disebutkan dalam Pasal 2 ayat (2) Undang-Undang Perkawinan, yaitu: "tiap-tiap perkawinan dicatat menurut peraturan perundang-undangan yang berlaku". Begitu juga pada Pasal 4 dan 5 dalam undang-undang yang sama berbunyi "Dalam hal seorang suami akan beristri lebih dari seorang (poligami), maka Ia wajib mengajukan permohonan ke Pengadilan di daerah tempat tinggalnya, dengan ketentuan jika istri tidak dapat menjalankan kewajibannya sebagai istri, istri mendapat cacat badan atau penyakit yang sulit untuk disembuhkan dan istri tidak dapat melahirkan keturunan, di samping itu harus ada persetujuan dari istri pertama, adanya kepastian suami mampu memberi nafkah isteri dan anakanaknya dan ada jaminan bahwa suami akan berlaku adil terhadap istri dan anak-anak mereka (Abdul Gani Abullah, 1991 : 187).

Perkawinan yang tidak dicatatkan di Indonesia dikenal dengan Istilah nikah di bawah tangan (kawin sirri). Hal ini banyak terjadi di Indonesia, baik di kalangan masyarakat biasa, para pejabat ataupun para artis, istilah populernya disebut istri simpanan. Perkawinan di bawah tangan sebenarnya tidak sesuai dengan "maqashid al-syar'iyah", karena ada beberapa tujuan syariah yang dihilangkan, diantaranya: 1) Perkawinan itu harus diumumkan (diketahui khalayak ramai), maksudnya agar orang-orang mengetahui bahwa antara A dengan B telah terikat sebagai suami istri yang sah, sehingga orang lain dilarang untuk melamar A atau B. 2) Adanya perlindungan hak untuk wanita, dalam perkawinan yang tidak dicatatkan pihak wanita banyak dirugikan hak-haknya, karena kalau terjadi perceraian pihak wanita tidak mendapatkan apa-apa dari mantan suaminya; 3) Untuk kemaslahatan manusia, dalam perkawinan yang tidak dicatat lebih banyak mudaratnya dari pada maslahatnya. Seperti anak-anak yang lahir dari perkawinan ini lebih 
tidak terurus, sulit untuk bersekolah atau untuk mencari pekerjaan karena orang tuanya tidak mempunyai Surat Nikah dan seandainya ayahnya meninggal dunia/cerai, anak yang lahir tidak mempunyai kekuatan hukum untuk menuntut harta warisan dari ayahnya. 4) Harus mendapat izin dari istri pertama, perkawinan kedua, ketiga dan seterusnya yang tidak mendapat izin dari istri pertama biasanya dilakukan di bawah tangan, sehingga istri pertama, tidak mengetahui bahwa suaminya, telah menikah lagi dengan wanita lain, rumah tangga seperti ini penuh dengan kebohongan dan dusta, karena suami selalu berbohong kepada istri pertama, sehingga perkawinan seperti ini tidak akan mendapat rahmat dari Allah (Abdul Gani Abullah, 1991 : 116).

Sahnya perkawinan, adalah apabila perkawinan itu telah memenuhi rukun dan syaratsyaratnya. Rukun perkawinan sebagaimana tercantum dalam pasal 14 Kompilasi Hukum Islam adalah sebagai berikut: 1) Calon mempelai suami, 2) Calon mempelai istri, 3) Wali Nikah, 4) Dua orang saksi, 5) Ijab kabul. (Inpres nomor 1 tahun 1991 tentang Kompilasi Hukum Islam, 2001: 10)

Sedangkan syarat perkawinan sebagaimana tercantum dalam pasal 6 UU. RI. Nomor 1 tahun 1974 adalah sebagai berikut: 1) Perkawinan harus didasarkan atas persetujuan kedua calon mempelai, 2) Kedua mempelai mencapai umur 21 tahun, jika kurang dari umur 21 tahun harus mendapat izin dari ke dua orang tua, jika wanita kurang dari umur 16 tahun dan pria kurang dari umur 19 tahun, maka harus mendapat izin dari Pengadilan (dispensasi kawin), 3) Tidak ada larangan menurut hukum Islam. (Undang-undang Nomor 1 tahun 1974 tentang Perkawinan, 2005 : 3)

Masyarakat Muslim Indonesia sudah meyakini bahwa rukun perkawinan adalah sebagaimana tersebut di atas, sehingga perkawinan (pernikahan) yang sudah memenuhi rukun tersebut di atas, maka perkawinan tersebut sudah dikatakan sah menurut hukum Islam, padahal ulama mazhab berbeda pendapat mengenai rukun perkawinan itu sendiri.

Menurut Imam Malik rukun pernikahan ada lima, diantaranya 1) Wali dari pihak perempuan, 2) Mahar (maskawin), 3) Calon mempelai laki-laki, 4) Calon mempelai perempuan, 5) Sighat akad nikah ( Abd, Rahman Ghazaly, 2003: 47-48).

Menurut Ulama Syafi'iyah rukun pernikahan ada lima, diantaranya 1) Calon mempelai lakilaki, 2) Calon mempelai perempuan, 3) Wali, 4) Dua orang saksi, 5) Sighat akad nikah. Sementrara Ulama Hanafiyah rukun perkawinan hanya ijab dan qabul saja (Abu Yahya Zakariya Al-Anshari, t.th :34).

Dari uraian di atas, pada dasarnya rukun perkawinan yang lima sebagaimana telah dijelaskan di atas tidak disepakati oleh imam mazhab, hanya ijab qabul saja yang telah disepakati sebagai rukun perkawinan oleh sebagian besar ulama mazhab, sedangkan yang 
lainya masih diperselisihkan. Oleh karena masih diperselisihkan, maka dapat disimpulkan rukun perkawinan yang lima itu belum baku (masih ijtihadi), oleh karenanya ada kemungkinan rukun pernikahan bisa bertambah atau bisa berkurang dari yang lima, sesuai dengan kebutuhan dan kemaslahatan umat manusia. Atas dasar pertimbangan di atas maka rukun perkawinan itu ada enam, dengan menambahkan pencatatan sebagai rukun perkawinan.

Dasar pencatatan sebagai rukun perkawinan adalah sebagai berikut :

1. Firman Allah dalam surat AnNisa ayat 59 yang berbunyi :

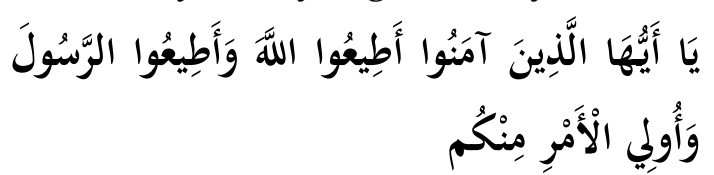

Hai orang-orang yang beriman, ta'atilah Allah dan ta'atilah Rasul (Nya), dan ulil amri di antara kamu."

Ahmad Musthafa Al-Maraghi menjelaskan yang dimaksud dengan "Ulil Amri" adalah pemerintah (Pemimpin), baik pemerintah pusat ataupun pemerintah di bawahnya, di mana tugasnya adalah memelihara kemaslahatan umat manusia. Dengan demikian aturan-aturan yang dibuat oleh pemerintah untuk kemaslahatan manusia wajib ditaati selama aturan-aturan tersebut tidak bertentangan dengan alquran dan sunnah. (Ahmad Musthafa AlMaraghi, t.th.: 72.)

Berbicara pemimpin dalam konteks keindonesian maka pemimpin dalam hal ini tetap adalah pemimpin dalam bidang agama.
Dalam hal ini mereka adalah orangorang yang ditunjuk oleh kepala pemerintahan untuk membuat suatu aturan yang diberlakukan secara umum bagi masyarakat Indonesia. Di Indonesia yang mewilayahi tersebut adalah Kementerian Agama dalam tugasnya dilaksanakan oleh Kantor Urusan Agama (KUA).

Ditinjau dari perspektif ilmu ushul fiqh, firman Allah tersebut di atas mengandung arti Amr (perintah), yaitu perintah untuk mentaati Allah, mentaati Rasul dan mentaati Pemimpin, sedangkan amr (perintah) ada yang mengandung wajib, ada yang mengandung $N a d b$ dan ada juga yang mengandung kebolehan. Untuk mengetahui katagori perintah apakah mengandung wajib, mengandung $N a d b$ atau mengandung kebolehan, hal ini perlu diketahui dari kepentingan perintah itu sendiri, atau qarinah yang mengikutinya.

\section{Sunnah Rasul}

Banyak sunnah Nabi yang menerangkan tentang perintah mentaati pemimpin, diantaranya hadis yang diriwayatkan dari Abu Hurairah Ra. artinya :

"Barang siapa yang mentaatiku maka ia telah mentaati Allah, barang siapa yang membantah kepadaku maka ia telah membantah kepada Allah, barang siapa yang mentaati pemimpin maka ia telah mentaatiku, dan barang siapa yang membantah pemimpin maka ia telah membantah kepadaku".

Hadis-hadis yang menerangkan tentang perintah mentaati pemimpin pada umumnya masih bersifat umum, tetapi sudah dapat 
dipastikan yang dimaksud dengan mentaati pemimpin di sini adalah apabila perintah-perintah itu tidak bertentangan dengan alquran dan sunnah. Ulama telah sepakat bahwa aturan-aturan yang telah dibuat oleh pemimpin Muslim di negara yang mayoritas penduduknya Muslim wajib ditaati apabila perintah itu untuk kemaslahatan manusia serta tidak bertentangan dengan alquran dan sunnah, sedangkan terhadap aturan-aturan yang dibuat oleh pemimpin yang non Muslim, ulama berbeda pendapat, sebagian golongan ada yang berpendapat boleh mentaati aturan-aturan yang dibuat oleh pemimpin yang non Muslim jika aturan tersebut tidak bertentangan dengan alquran dan sunnah, sedangkan sebagian lagi berpendapat tidak boleh mentaati aturan-aturan yang dibuat oleh pemimpin non Muslim sekalipun aturan-aturan tersebut tidak bertentangan dengan alquran dan sunnah, karena aturan-aturan yang dibuat oleh Non Muslim adalah bathal. Dengan demikian dapat dipahami aturan-aturan yang dibuat oleh Pemerintah Indonesia dalam hal ini kementerian Agama yang mana aturan-aturan tersebut dibuat oleh orang-orang Muslim untuk kemaslahatan Umat Islam, maka peraturan-peraturan itu wajib untuk ditaati.

Pada dasarnya maqasid alsyariah dari perkawinan adalah agar manusia hidupnya damai penuh dengan kasih sayang satu dengan yang lainnya, karena unsur dari kejadian manusia adanya pemenuhan kebutuhan biologis untuk malanjutkan keturunan, sehingga dengan perkawinan itu manusia akan terhindar dari perbuatan yang keji dan kotor yang bisa menimbulkan kejahatan dan kerusakan. Keturunan yang diharapkan oleh syariah adalah keturunan yang dapat menjalankan aturan-aturan Allah yang berupa perintah dan larangan. Sebab terlaksananya perintah-perintah Allah akan terciptanya kemaslahatan dan kedamaian dalam dunia ini, sedangkan dengan tidak terlaksananya perintah-perintah Allah akan terciptanya kerusakan dan kemadharatan dalam dunia ini.

Tujuan syariah lainnya adalah terpeliharanya keturunan-keturunan yang akan melanjutkan misi Allah di muka bumi, perkawinan seorang pria yang dilatarbelakangi hanya karena kebohongan belaka atau karena memenuhi nafsu biologis saja, akan mengakibatkan tidak terpeliharanya turunan-turunan baik dari segi pendidikan, agama ataupun mental, sehingga akan mengakibatkan timbulnya kerusakan dan kemadharatan bagi anak-anak itu sendiri. Dengan adanya pencatatan maka kedudukan anak serta status anak akan semakin jelas yang bisa diketahui turunannya, sehingga ia berhak untuk mendapatkan atau menuntut sesuatu dari ayahnya, sedangkan apabila perkawinan itu tidak dicatatkan maka hak-hak anak akan terabaikan.

Dengan demikian $\begin{gathered}\text { dapat } \\ \text { disimpulkan } \\ \text { pahwa }\end{gathered}$ tujuan
agar hidup manusia di dunia ini


penuh dengan kedamaian dan kasih sayang antara yang satu dengan yang lainnya, manusia yang mempunyai tugas sebagai khalifah fil ard untuk tetap menjalankan misimisi Allah di muka bumi ini dengan menjalankan aturan-aturan yang telah ditetapkan oleh Allah ataupun Rasul-Nya yang berupa alquran dan hadis, sehingga dunia ini penuh dengan kedamaian dan kemaslahatan bagi umat manusia. Akan tetapi kedamaian dan kemaslahatan tidak akan tercapai jika tidak ada aturan-aturan pendukung lainnya yang lebih spesipik yang berupa al-Maslahah al-Mursalah, oleh karena itu Pemerintah Republik Indonesia telah membuat aturan-aturan yang berupa UU. Nomor 1 tahun 1974, PP. Nomor 9 tahun 1975, UU. Nomor 7 tahun 1989, Kompilasi Hukum Islam dan lain sebagainya.

Menurut Imam Asy-Syathibi “ jika aturan/hukum itu membawa kepada kemaslahatan, maka aturan /hukum itu harus dijadikan sebagai pegangan, dengan kriteria 1). Tidak bertentangan dengan maqashid alsyariah yang dharuriyyah, hajiyyat dan tahsiniyyat, 2).Rasional, dalam arti bisa diterima oleh orang cerdikcendikiawan (ahl al-dzikr), 3). Menghilangkan kesulitan “.(AsySyathibi, t.th : 172.)

Dengan demikian karena pencatatan perkawinan mendatangkan kemaslahatan, maka sudah seharusnya pencatatan perkawinan itu dijadikan salah satu rukun perkawinan pada saat sekarang ini, oleh karena itu perkawinan yang tidak dicatatkan berarti tidak memenuhi rukun perkawinan, karena tidak memenuhi rukun perkawinan, maka sudah dipastikan perkawinan yang tidak dicatatkan tidak sah menurut hukum Islam. Pada ayat dua (2) Kompilasi Hukum Islam disebutkan "Sahnya pencatatan itu harus dilakukan oleh Petugas Pencatat Nikah (KUA)", analoginya jika pencatatan itu dilakukan oleh bukan Petugas Pencatat Nikah, maka nikahnya tidak sah, karena selain PPN (KUA) tidak memiliki kewenangan untuk mencatatkan atau melangsungkan pernikahan. Begitu juga pada pasal 6 ayat (1) KHI berbunyi " untuk memenuhi ketentuan pasal $5 \mathrm{KHI}$, setiap perkawinan harus dilangsungkan di hadapan dan di bawah pengawasan Pegawai Pencatat Nikah". Kata "harus" juga diartikan wajib, artinya perkawinan itu wajib dilakukan di hadapan Petugas Pencatat Nikah, oleh karena itu perkawinan yang dilakukan di luar Petugas Pencatat Nikah maka nikahnya tidak sah pula menurut hukum Islam (Soleman Saleh, 2008 : 23).

Kantor Urusan Agama (KUA) adalah lembaga yang telah ditunjuk (tauliyyah) oleh Presiden Republik Indonesia untuk menangani masalah perkawinan bagi orang yang beragama Islam, sehingga para Petugas Pencatat Nikah KUA telah disumpah oleh Pemerintah agar mereka dapat menjalankan tugas sesuai yang diamanatkan dan sesuai dengan jabatan yang diembannya. Dengan tauliyyah itu KUA mempunyai kewenangan yang mutlak untuk menangani masalah 
pernikahan bagi yang beragama Islam, dengan demikian lembagalembaga lain baik yang dibuat oleh pemerintah ataupun lembaga swasta, golongan ataupun pribadi tidak mempunyai kewenangan untuk melaksanakan pernikahan.

Berdasarkan kaedah maslalah bahwa tujuan syarak adalah untuk memelihara kemaslahatan umat manusia, maka pencacatan perkawinan menjadi sebuah kemestian yang tidak dapat di abaikan. Karena dengan pencatatan perkawinan inilah akan terjamin hak-hak dari berbagi pihak. Sehingga tercapailah apa yang di inginkan oleh syarak, yaitu mendatangkan kemaslahatan dan menolak kemudharatan.

Menurut

maslahah adalah

Zuhaili, 1996: 757)

المحافظة على مقصود الشرع بدفع الفاسد عن

الخلق

Memelihara tujuan syarak yaitunya menolak kemudharatan terhadap manusia.

Pengertian maslahah di atas menjelaskan bahwa tujuan dari hukum itu adalah untuk memelihara tujuan syarak yaitu mendatangkan kemaslahatan dan menolak kemudaratan bagi umat manusia. Dalam hal ini kemaslahatan itu harus dijaga dalam segala aspek kehidupan. Termasuk kemaslahatan yang harus dijaga tersebut adalah dalam masalah pernikahan.

Selanjutnya jika dicermati Fatwa MUI nomor 10 tahun 2008 tentang Nikah di bawah tangan, bahwa Pernikahan di bawah tangan hukumnya sah karena telah terpenuhi syarat dan rukun nikah, tetapi haram jika terdapat madharat. Dan pernikahan harus dicatatkan secara resmi pada instansi berwenang, sebagai langkah preventif untuk menolak dampak negatif atau mudharat (sadd al-zariah) (Fatwa MUI nomor 10 tahun 2008 tentang Nikah Bawah tangan).

Ungkapan yang terdapat dalam fatwa ini tetap mengedapankan pencacatan, karena sah pun perkawinan tetapi tidak memiliki kekuatan hukum sudah tentu akan menimbulkan mudharat. Sementara jika perkawinan di bawah tangan mendatangkan mudharat maka hukumnya haram. Dan fenomena yang terjadi di masyarakat bahwa dalam nikah di bawah tangan atau yang tidak dicatatkan dampak terburuk sering dirasakan oleh istri dan anak-anak. Karena ketika akan menuntut haknya mereka tidak punya bukti yang dapat menguatkan gugatannya. Sehingga tujuan hukum untuk mendatangkan kemaslahatan tidak tercapai.

Selanjutnya pada tahun 2010 Mahkamah Konstitusi dalam putusan Nomor 46/PUU-VIII/2010 menetapkan "Anak yang dilahirkan di luar perkawinan mempunyai hubungan perdata dengan ibunya dan keluarga ibunya serta dengan laki-laki sebagai ayahnya yang dapat dibuktikan berdasarkan ilmu pengetahuan dan teknologi dan/atau alat bukti lain menurut hukum mempunyai hubungan darah, termasuk hubungan perdata dengan keluarga ayahnya"; 
Menurut hemat penulis putusan ini dikhawatirkan secara tidak langsung melegalkan nikah sirri yang tentu akan bertentangan dengan prinsip maslahat. Lebih jauh lagi keberadaan pasal-pasal yang mengatur tentang aturan perkawinan baik rukun dan syarat menjadi tidak berwibawa lagi. Sehingga gerakan untuk menuju Indonesia tertib barangkali akan menjadi sebuah mimpi yang sulit diwujudkan .

Lebih jauh lagi jika dilihat kilas balik sejarah adanya aturan pencatatan nikah ini sudah berlaku sejak Indonesia merdeka, yang tertuang dalam Undang-Undang No. 22 Tahun 1946. Dalam Undang undang tersebut dinyatakan bahwa nikah diawasi oleh pegawai Pencatat Nikah (PPN) yang diangkat oleh Menteri Agama. Di samping itu, talak dan rujuk yang dilakukan berdasarkan syariat Islam diberitahukan kepada PPN. Selanjutnya dalam UU tersebut juga dinyatakan bahwa'seseorang yang menikah diwajibkan membayar biaya pencatatan yang jumlahnya ditatapkan oleh Menteri Agama. Selanjutnya jika nikah tidak di bawah pengawasan PPN atau wakilnya dihukum denda sebanyakbanyaknya lima puluh rupiah. Dan bagi yang menikahkan tanpa pengawasan PPN maka dihukum kurungan selama tiga bulan atau denda seratus juta rupiah. (Jaih Mubarok, 2015 :65-66)

Jika dicermati Undangundang tentang perkawinan mulai Undang-Undang No. 22 Tahun 1946, Undang-undang No. 1 Tahun 1974,
Kompilasi Hukum Islam memang tidak ada memuat tentang hukum tidak sah menikah tanpa dicatatkan tetapi barangkali untuk kemaslahatan dan terjaganya hakhak perempuan dan anak maka barangkali jika beragam macam cara menafsirkan hukum sebagaimana yang disampaikan oleh J.C.T. Simorangkir dan Woerjono Sastropranoto sebagaimana yang dikutip oleh Jaih Mubarok dalam bukunya Pembaharuan hukum Islam Indonesia dengan penafsiran historis. (Jaih Mubarok, 2015 :64)

Lebih jauh lagi berbicara persoalan maslahah dalam pernikahan maka persoalan tersebut masuk kategori maslahah yang dharuriyyah yaitu pada level menjaga nasab atau keturunan. Sehingga hal tersebut adalah sesuatu yang harus dijaga dalam berbagi kondisi dan zaman. Sehingga barangkali apa yang tertuang dalam draf KHI tahun 2004 bahwa pencacatan nikah adalah salah satu rukun nikah menurut hemat penulis sudah menjadi kemestian. Dan ini sejalan dengan prinsip syara' yaitu mendatangkan kemaslahatan. Karena dengan di jadikannya pencatatan nikah sebagai rukun nikah hampir dipastikan tidak ada mudharat yang akan timbul. Apalagi ditambah dengan adanya PP No. 48 tahun 2014 tentang tarif pelaksanaan nikah dan rujuk yang menyatakan bahwa pernikahan yang dilakukan di KUA pada hari dan jam kerja tarifnya nol rupiah. Ini semakin menguatkan untuk mencatatkan nikah. Barangkali jika masih ada yang nikah di bawah tangan, perlu 
dipertanyakan ada apa dalam pernikahan tersebut?

\section{PENUTUP}

Dari uraian di atas dapat diambil kesimpulan bahwa jika pencatatan perkawinan dijadikan sebagai rukun maka dapat dipastikan tidak ada mudharatnya. Karena dengan dicatatkannya perkawinan maka akan terjamin hak-hak istri dan anak. Untuk menghilangkan kemudaratan dan mendatangkan kemaslahatan dalam pernikahan ini perlu adanya aturan yang tegas. Dalam hal ini maka untuk kemaslahatan pencacatan nikah adalah suatu keharusan. Sehingga menjadikan pencatatan bagian dalam rukun nikah menjadi sebuah kemestian.

\section{DAFTAR KEPUSTAKAAN}

Abidin, Slamet dan Aminuddin, ,1999. Fiqih Munakahat 1, Bandung: Pustaka Setia

Abdullah, Gani Abdul, 1991. Himpunan Perundang-undangan dan Peraturan Peradilan Agama, Jakarta : PT. Intermasa

Abd al- Baqi, Muhammad Fuad, 1987. al- Mu'jam al- Mufahras li al-Faz al-Quran al- Karim, Beirut : Dar al-Fikr

Al-Kahlani, Muhammad Ismail, t.th, Subul al- Salam. Bandung : Pustaka Dahlan

Al-Maraghi, Ahmad Musthafa, t.th. Tafsir Al-Maraghi, Makkah alMukaramah : Al-Maktabah AtTijariyah
al-Zuhaili , Wahbah, 1996. Ushul alfigh al-Islamy, Beirut ; Dar- alFikr 1996, Al-Figh alIslam wa Adillatuhu, Beirut ; Dar- al-Fikr

Asy-Syathibi. T.th. Al-Muwafaqat fi Ushuli al Syariah. Mesir : AlMaktabah al-Tijariyah

Fatwa MUI nomor 10 tahun 2008 tentang Nikah di bawah tangan,

Ghazaly Abd, Rahman, 2003. Figh Munakahat. Jakarta: Prenada Media.

Inpres No. 1 tahun 1991 tentang Kompilasi Hukum Islam

Mubarok, Jaih, 2015, Pembaharuan Hukum Perkawinan di Indonesia, Bandung : Simbiosa Rekatama Media

Nuruddin, Amiur, Dkk, 2004. Hukum Perdata Islam Di Indonesia, Jakarta : Kencana.

Soleh, Sulaiman, 2008. Perkawinan dan Perceraian di bawah Tangan ditinjau dari Hukum Islam, http//: perkawinan dan perceraian di bawah tangan,pdf//, di akses tanggal 27 Desember 2010

Undang-undang No. 1 tahun 1974 Tentang Perkawinan

Widiaismara, Eka, Kedudukan Perkawinan dan Perceraian di bawah Tangan di tinjau dari Hukum Islam dan Peraturan Perundang-undangan yang Berlaku di Indonesia, http// :Kedudukan Perkawinan dan Perceraian di bawah Tangan di tinjau dari Hukum Islam dan Peraturan Perundang-undangan yang Berlaku di Indonesia, pdf//, diakases Tanggal 27 Desember 2010 
Zakariya Al-Anshari, Abu Yahya. t.

Fikri

th. Fathul Wahab. Beirut :Darul 